\title{
Model of Crisis Communication Management in the Perspective of Situational Crisis Communication Theory at the Transportation Ministry
}

\author{
http://dx.doi.org/10.25008/jkiski.v5i2.408 \\ Ari Sulistyanto ${ }^{1}$, Usmar ${ }^{2}$, Hermiyetti ${ }^{3}$ \\ ${ }^{1}$ Faculty of Communication Sciences, Universitas Bhayangkara Jakarta Raya \\ J1. Harsono RM No.67 Ragunan, Jakarta 12140 - Indonesia \\ ${ }^{2}$ Faculty of Economy, Universitas Prof. Dr. Moestopo (Beragama), \\ Jalan Hang Lekir 1 No.8 Senayan. Jakarta 10250 - Indonesia \\ ${ }^{3}$ Faculty of Business Economics, Universitas Bakrie, \\ Jl.H.R Rasuna Said Kav C-22, Jakarta - Indonesia \\ *Corresponding author: ari.sulistyanto@dsn.ubharajaya.ac.id
}

Submitted: September 17, 2020, Revised: November 28, 2020, Accepted: December 25, 2020

Accredited by Kemristekdikti No. 28/E/KPT/2019

\begin{abstract}
Rapid disaster response is necessary since it involves various stakeholders in disaster. However, rapid response is difficult to implement due to structural constraints and organizational hierarchy. This research aims to reveal structural constraints to crisis communication management in the internal organization of the Transportation Ministry. Situational Crisis Communication Theory (SCCT) approaches offer a framework to understand management in general in responding to crisis situation. This research uses a qualitative method with case study approaches. The results of this research show that in the pre-crisis phase the organization serves as media for sections at the Transportation Ministry to interact in monitoring potential crisis. In the crisis and post-crisis response phases, the establishment of an Ad Hoc Crisis Communication Team (TKK) has changed the organization from being under stringent hierarchic structure to being more flexible and responsive in crisis response. This research gives contributions to more dynamic crisis communication management, recommends the formulation of Standard Operating Procedure (SOP) in crisis communication management, starting from pre-crisis, crisis to post-crisis response phases, and gives guidance to government and non-government organizations in crisis communication management.
\end{abstract}

Keywords: Rapid disaster response; crisis communication; situational crisis; internal organization;

\section{Introduction}

Rapid response from stakeholders is needed to handle transportation-related disaster. Rapid response is to communicate everything related to the disaster (Khosla, 2017; Asteria, 2016), including scene of disaster, cause of disaster and victims of disaster. Such communication is important to avoid miscommunication and confusion on the part of the victims' family members and the general public. Likewise, stakeholders related to the disaster can handle it soon.

Rapid response is sometimes difficult to do. This is because of structural constraints within the internal organization and this poses a challenge within the organization (Roux, 2019). The organizational structure constraints are common in disaster response, particularly when a group of people accustomed to hierarchy and centralized decision-making suddenly work in a flatter and more dynamic organizational structure (Manoj and 
Baker, 2007; Bundy et al., 2017). In fact, rapid disaster response brings about reputation, performance and credibility of the organization in the eyes of the public (Al Shobaki et al,2016).

Such is the case with disaster response at the Transportation Ministry. As a transportation regulator, the ministry often faces constraints to crisis communication management. The Public Communication and Information Agency (BKIP) at the Transportation Ministry disclosed several examples of failed crisis communication management in handling a disaster (BKIP, 2019 For instance, the sinking of MV Sinar Bangun in Lake Toba on June 18, 2018 which claimed 3 lives and the tragedy of Lion Air JT 610 which crashed into waters off Karawang coast while on its flight from Jakarta to Pangkal Pinang and killed all its passengers and crew members.

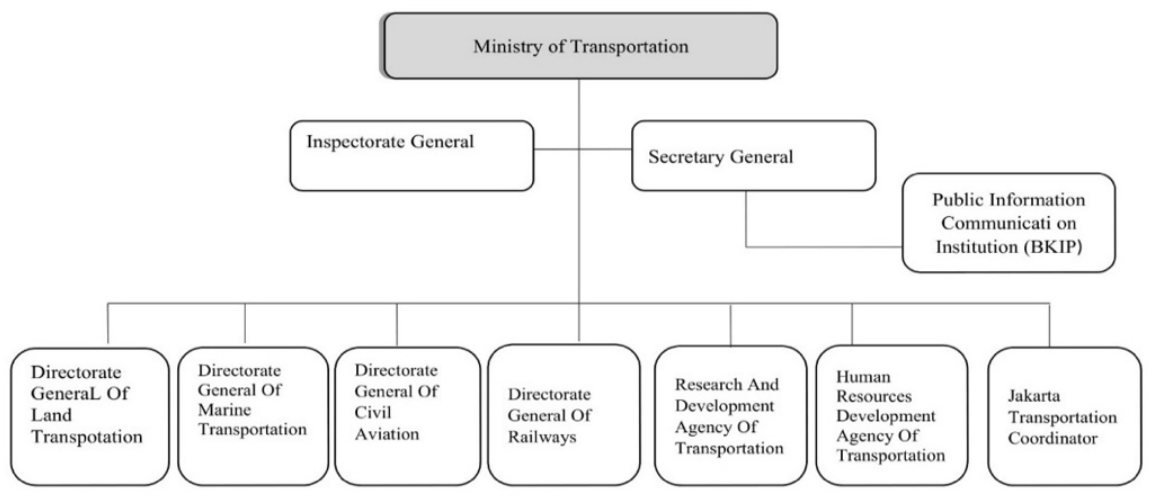

Figure 1. Organizational Structure of the Transportation Ministry

Source: Minister of Transportation Regulation No. 122 of 2018

The failure came under the spotlights from the House of Representatives (DPR) which stated the Transportation Ministry was slow to inform the public of the plane crash. The government's slow response was because it announced the tragedy only at 09.00 WIB after the SAR Office in Jakarta reported it at 07.00 WIB. (Muslimin, 2018).

The slow response was the result of organizational hierarchy and bureaucracy which failed to give a chance to work with a high level of reliability. In managing public communication as shown in Figure 1, the Transportation Ministry subordinates the Directorate General of Land Transportation, the Directorate General of Sea Transportation, the Directorate General of Air Transportation and the Directorate General of Railway.

Each of the Directorate Generals has Communication Working Unit (UKK), popularly known as the Public Relations Division (Humas) in charge of public communication at the Directorate Generals. Meanwhile, UKK or the Public Relations Service at the Transportation Ministry is within the purview of the Communication and Public Relations Board (BKIP) responsible to the Secretary General.

Problems arise when one of the UKKs at the Directorate General of Air Transportation (Ditjen Hubud) is encountered with disaster response, for instance, plane accident. On one hand, it becomes the responsibility of the UKK at Ditjen Hubud, but because of limited authority and information access it did not immediately conduct public communication. On the other hand, BKIP has no direct authority to make a decision to conduct disaster response because it is subordinated to the Secretariat General and has no hierarchic relations with the UKK of the UKK at Ditjen Hubud. This leads to lack of crisis identification, lack of coordination among sections, and the absence of quick decision making system. For the purpose of external communication, particularly with mass media, there has not been system of selecting credible personnel to convey messages and key messages.

Having learned the case, the problems faced by the government organization are related to structural constraints, and the absence of collective understanding within the organization about whether or not crisis communication management is needed in the event of disaster. In fact, each organization will face a crisis anytime and needs to make preparations for communication with stakeholders, either internal or external (Strandberg \& Vigsø, 2016). Hence, disaster, as a reality, moves to the need for preparation and preparedness to respond, known as crisis management (Matthew Collins et al., 2016).

Currently, a study of internal crisis communication is considered new and tends to go unheeded (Adamu, 2016). A study of crisis communication is more oriented to external organizational crisis communication, namely relations between stakeholders/crisis-controlling organization and crisis-related organization or institution. For instance, research of organization 
protecting their reputation during a crisis (Elliot, 2010); the impact of media and spokesperson on stakeholders' response (Brown, \& Billings, 2013); the strategy of crisis communication (Adamu, 2016); the management of communication disparities in identifying crisis between expert of the government and NonGovernmental Organization (Palttala, et al, 2012; Lestari et al., 2012); difference in the method of conveying information via social media between regional government and residents affected by disaster (Hong, et al, 2018); perception of social media use for crisis communication between the government and Non-Governmental Organization (Ly-Le, 2018); strategy of responding to crisis communication within a trade association (Frandsen \& Johansen, 2018).

Other researches on crisis communication at an internal organization include preparedness of an organization for a crisis to maintain reputation and build trust (Wowak, et al, 2015; Roshan, et al, 2016; Mazzei, 2015); leadership in an organization in times of crisis (Brown, et al, 2016; Cardon, 2019); employees' perspective of narration, culture and supervision (Strandberg \& Vigsø, 2016; Ravazzani, 2016); internal conflict within an organization in facing crisis (Purworini, 2017); monitoring information via online media in times of crisis (Dominguez-Lopez, 2017; Zeng et al., 2017); motivation language of leaders (Farida \& Ganiem, 2017).

All the researches have yet to explain specifically crisis communication management in a hierarchic and bureaucratic organizational structure. Of course, a lack of studies on the subject is worth regretting. In fact, the studies are important to guide government and nongovernment organizations which are accustomed to applying a centralized decision-making system with a stringent hierarchic structure in disaster response. Weick (2001) suggested that organizations with a high level of reliability have the capacity to manage unpredicted events (Bundy et al., 2017).

Through Situational Crisis Communication Theory approaches, this research is expected to contribute to knowledge by exploring sub-sections of the organization to monitor whether there is potential crisis or how the organization works in the pre-crisis phase. This research also describes the transformation of the organization from being under stringent hierarchic structure and decisionmaking system to being a dynamic organization in the crisis response phase and working in the recovery and crisis evaluation phase. Hence, this research produces a model of crisis communication management in the pre-crisis, crisis and post-crisis phases.

\section{Theoretical Framework}

The concepts of Crisis and Disaster have different meanings. According to Coombs (2007), the definition of crisis depends on four criteria: uncertainty, threat to stakeholders' hope, impact on the organization's performance, and potential negative outcome. This definition resembles Ulmer's view (2016) which also relies on four aspects; unexpected happening, non-routine demand at the organization, uncertain production, and threat to high priority goals (Ulmer, 2016; Sellnow,2015; Coombs, 2010a).

Based on the criteria, crisis is understood as an unexpected and unpredictable happening, which is caused by several types of event, can threaten stakeholders' hope, brings about nonroutine performance, leads to uncertainty which have a negative impact on the organization's performance and threatens the organization's goals, thereby tarnishing the image and reputation of the organization.

Unlike crisis, "disaster" is an external event that threatens the organization's reputation (Adkins, 2010; Lestari et al., 2019; Wahyuni, 2019). For instance, disasters caused by nature, such as earthquake and tsunami, and disasters caused by human errors, such as accidents in the transportation sector. Crisis is a negative form derived from internal weaknesses within an organization disclosed while trying to respond to external stimulus, such as disaster or attack on the organization's credibility. Since crisis is caused by the organization's weaknesses, it can inherently be avoided.

Basically, disaster is beyond the organization's control and in practice, cannot be avoided. Thus, to minimize the negative outcome of a disaster which will potentially turn into a crisis, the organization can avoid it by controlling precisely the organization's behavior before and during the disaster. To that end, it needs any inclusive capital found in the communication network in the standby phase to face the disaster (Wardyaningrum, 2016).

Thus, on one hand, the organization needs crisis management with the aim of preventing or reducing the negative outcome of a crisis which may have an impact on the effort to protect the organization, stakeholders and industry from destruction. As a process, crisis management comprises many elements such as preventive action, crisis management plan and post-crisis evaluation (Coombs, 2007). On the other hand, the organization needs widely-understood crisis 
communication as a means of gathering, processing and disseminating information needed to handle crisis.

\section{Situational Crisis Communication Theory}

Situational Crisis Communication Theory (SCCT) approaches lay a foundation for checking the attribution of responsibility influencing the reputation of the organization, and showing the organization through response strategy to adapt to its authority in reducing threat to the organization's reputation due to crisis (Adkins, 2010b:). This theory is also used particularly to study how reputation influences responsibility to an organization and how response strategy of protecting reputation matches responsibility owned (Ma \& Zhan, 2016).

In keeping with Attribution Theory, SCCT is one of the most influential theories used to understand crisis and crisis response strategy (Coombs, 2007). The theory developed in 1995 is derived from a simple premise, that is crisis is a negative event, stakeholders will make attribution of crisis responsibility, and the attribution will influence how stakeholders interact with the organization in crisis. Attribution has a significant impact on how the public view the reputation of the organization in crisis and their effective response and attitude to the organization after crisis (Coombs, 2007).

This theory uses three-staged approaches modified from pre-crisis, crisis and post-crisis phases (Coombs, 2010b). The stages constitute a set of factors forming crisis management (Vardarlier, 2016). Pre-crisis phase involves efforts to prevent crisis and prepare crisis management. In this stage, crisis communication revolves around activities, ranging from gathering information about crisis risks, making a decision on how to manage potential crisis, to training people to get involved in crisis management process.

SCCT is part of model of anticipation concentrated on the placement and reduction of risks. Prevention is the main priority for anticipative model. This model uses vigilance during the pre-crisis phase to help decision-making and crisis prevention (Olaniran, 2008). Thus, it is important to monitor pre-crisis messages as an input to recommend policy makers to conduct crisis response. By using biological analogy, precrisis messages give early information about potential crisis and help formulate a strategy to respond to negative reaction from the public and media.

In times of crisis, response to the actual occurrence is needed (Kádárová,et al, 2015). Sturges (1994) gives a framework which is useful to categorize crisis responses based on strategy focus. First, giving information, how to overcome crisis physically; second, adjusting information, how to overcome crisis psychologically; and third, improving reputation, an effort to improve damage caused by crisis to the organization (Coombs, 2010b). The instructed information strategy portrays how the organization can protect itself from crisis, remind people of crisis and how to protect them from physical danger.

Information adjustment strategy offers a useful strategy to help the organization overcome crisis psychologically, evoke an expression of sympathy, provide information about crisis events, offer counseling and take corrective action.

Post-crisis is an effort to learn from crisis events (Bundy, et al, 2017). Since it is difficult to find accurately when crisis is over, post-crisis communication is mostly the expansion of crisis response communication, coupled with learning from crisis (Coombs, 2007). Crisis gives a chance to evaluate what the organization has done, including what has caused the crisis and what crisis management effort has been made.

Crisis is something negative. Thus, rapid response is needed to prevent it from disrupting image, reputation and credibility. Government organizations, such as the Transportation Ministry are usually more oriented to mechanistic model in their bureaucratic governance (Andhika, 2018). This model much portrays a rigid and tightlycontrolled organization, a high level of hierarchy, clarity of control, role and task of bureaucracy, and centralized decision making. Mechanistic structure has great potential to obstruct performance to get faster. Through SCCT approaches, bureaucratic parturitions obstructing rapid response will be able to move dynamically in handling crisis. Thus, crisis communication management at the Transportation Ministry focuses on pre-crisis, crisis and post-crisis phases.

\section{Material and Methodology}

This research uses a qualitative method with case study approaches. This research comprises two phases. The first phase is literature study, that is to learn and study law, presidential regulation and ministerial regulations related to public communication management at the Transportation Ministry. The law and regulations are: (1) Law No. 39 of 2008 concerning State Ministries, (2) Presidential Regulation No. 40 of 2015 concerning the Transportation Ministry, (3) Regulation of the Transportation Minister No. 122 of 2018 concerning the Organization and Work Procedure of the Transportation Ministry, (4) Regulation of 
the Transportation Minister No. 38 of 2019 concerning Public Communication Management.

This step was taken to see a judicial and practical basis for the execution of tasks and authority in the land, sea and air transportation subsectors, the operation of Jabodetabek railway lines, and the Public Communication and Information Bureau (BKIP) in crisis communication management so as not to cause their responsibility and authority to overlap.

The second step was to hold Focus Group Discussion (FGD) with BKIP, land, sea and air sub-sectors, the operator of Jabodetabek railway lines at the Transportation Ministry. The FGD was held in three sessions. The first session, identifying internal problems faced by the Transportation Ministry in crisis communication management, such as the tasks and authority of persons in charge of public communication, structural constraints, and disagreement in viewing crisis.

The second session, discussing various regulations related to public communication and crisis communication management. The third session, discussing understanding between UKK, the Inspector General, the Director General and the Board, along with BKIP in crisis communication management, ranging from pre-crisis phase, making a decision on the formation of Crisis Communication Team, crisis response phase, to post-crisis phase.

\section{Result and Discussion}

The study of Law and Regulation of the Transportation Minister in crisis communication management refers to Regulation of the Transportation Minister No.38, Chapter I Article I paragraph 1: "Crisis Communication Management is the process of managing strategic issues predicted to have crisis potential before it turns into crisis communication, and managing policy, resolving problems in the recovery stage to prevent destructive situation which has the potential to inflict large losses on the institution, the public, human resources, and stakeholders" (Regulation of the Transportation Minister of the Republic of Indonesia No. 38 of 2019)

The Transportation Ministry has defined crisis communication management. The rule serves as a legal umbrella that crisis communication management is done before negative issues develop into crisis. In public communication management, pursuant to Regulation of the Transportation Minister No. 38 of 2019, Chapter II Article 3 paragraph 1, each of the sub-divisions has the authority to conduct public communication management. For instance, the Communication Working Unit at the Transportation Ministry is the working unit responsible for the public communication field at the Secretariat General. The Communication Working Unit of the Inspectorate General is the working unit responsible for the public communication field at the Inspectorate, and so on (Regulation of the Transportation Mnister of the Republic of Indonesia No. PM 38 of 2019, 2019).

Such authority structure causes redundancy or even confusion about which sub-section must take responsibility in the event of transportation disaster which will potentially cause crisis and need further crisis communication management, such as the crash of Lion Air plane JT 610 in the waters off Karawang coast. The accident information is the authority and responsibility of the Directorate General of Air Transportation. Hence, the public communication management rests with the Communication Working Unit at the Directorate General of Air Transportation. But because the disaster has a national and even international scale impact, the Communication Working Unit at the Directorate General of Air Transportation did not immediately conduct public communication management while awaiting instruction from its superior. Consequently, information was sent slowly, thereby disrupting the image and reputation of the Transportation Ministry.

Pursuant to Regulation of the Transportation Minister No. 38 of 2019, Chapter II Article 4 paragraph 1, the Public Communication and Information Board (BKIP) subordinated and responsible to the Secretariat General of the Transportation Ministry has the authority to coordinate and integrate public communication activities. In addition, the BKIP also supervises, monitors and detects early potential crisis communication. Each of the communication working units, along with the BKIP monitor information or issue pointing to potential crisis. In the event of information or issue pointing to the escalation of potential crisis, the UKK at the Directorate General and BKIP coordinate with the Secretariat General of the Transportation Ministry in taking further steps.

\section{Crisis Communication Identification Phase}

Regulation of the Transportation Minister No. 38 of 2019, Chapter IV Article 20 carries the procedure of managing crisis communication at the Transportation Ministry in the event of transportation disaster or other events having the potential to cause crisis and disrupt reputation, image and public trust in the Transportation Ministry. 
Crisis communication can be distinguished into anticipatable crisis communication and unanticipatable crisis communication. Crisis communication management comprises stages and procedures, including analyzing strategic issues, monitoring mass media and social media, reporting news having the potential to cause crisis, and clarifying and denying negative issues to prevent them from turning into bigger crisis.

Unanticipatable crisis usually happens to transportation disaster, such as in the land, sea, air and railway transportation sectors. Transportation disaster emerges suddenly and must be handled immediately. Thus, crisis communication management is important to anticipate negative issues that have the potential to disrupt the credibility of the Transportation Ministry.

Anticipatable crisis communication usually emerges in stages. Thus, monitoring is limited to making an inventory of cases that may turn into potential crisis. Types of cases that can be identified at the Transportation Ministry include, (1) transportation regulations, (2) transportation accident, (3) congestion, (4) ticket hike, (5) corruption red-handed operation (Regulation of the Transportation Minister of the Republic of Indonesia No. PM 38 of 2019).

Crisis communication management is a cycle starting from normal condition of transportation management, having potential to change into a crisis, to getting back to normal condition. Thus, understanding the potential for crisis communication is important, as shown by the parameters: (1) negative reporting by various types of mass media, (2) negative opinion in social media and online media, and, (3) event or case causing the negative image or reputation of institution, which leads to the loss of lives, physical damage and material losses.

Potential crisis can be observed by monitoring news stories in mass media and online media, through the following stages: (1) monitoring mass media, both print media and online media, or negative chats in social media, (2) rating negative issues, (3) giving a conclusion to arising attributes as to whether they are positive, neutral, or negative, (4) using the ratings as referred to in point (2) to lay a basis for deciding issues having the potential to cause crisis by observing the movement of attributes to see whether they move in the negative direction or in the neutral and positive direction.

Pre-Crisis Phase

Coombs (2007) in Parameters for Crisis Communication reveals steps to detect potential crisis communication (Coombs, 2010b). This initial step is called pre-crisis phase. In this stage, the main thing to do is to gather information by monitoring information from mass media and social media. Signal detection, prevention and preparation are part of pre-crisis phase (Coombs, T. Holladay, 2010). In early detection phase, it is the task and responsibility of UKK at the Directorate General and BKIP to monitor information on potential crisis. Information from mass media, online media and social media is monitored regularly and permanently.

If there are findings from UKK at the Directorate General and the result of monitoring by BKIP shows the escalation of negative issues, to strategic macro level, namely cross sectoral, national and international impact, the Chief of BKIP informs the Transportation Ministry though the Secretary General about the potential crisis and recommends the creation of crisis handling institute. This is the initial stage to hold communication through a joint meeting among sub-sectors at the Transportation Ministry. The meeting decided the need to adopt crisis management. Preparations and crisis communication plan were late made by setting up Crisis Communication as an ad hoc institution

\section{The Establishment of Crisis Communication Team}

When the monitoring of information indicates potential crisis, a meeting will later be held to decide its status. This stage is realized at a joint meeting of UKK at the Directorate General, BKIP and Secretariat General of the Transportation Ministry. The period of time between a report and decision making is less than 1 hour. The period of time is meant to make rapid response. At the meeting there are 2 alternative decisions. First, crisis communication management is only handled by UKK of the Directorate General because it is predicted not to expand and to be on small scale. Second, crisis communication management should be followed up on because the crisis is expected to spread and disrupt the image and reputation of the organization.

In the monitoring phase until the status is decided. If the meeting decides the need to follow up on crisis communication management, the crisis communication team will begin to work and take responsibility, starting from the crisis response phase to post-crisis phase. This is done by considering that crisis communication management needs indefinite time to predict when the crisis will be over. Hence, all models of coordination and control are adopted by the Crisis Communication Team (TKK) for the purpose of public communication.

The institutional scope of the Crisis Communication Team (TKK) is ad hoc in nature. 
The personnel of TKK, as provided for by Ministerial Regulation No. 38 of 2019 concerning Public Communication Management, are the combination of public communication management officials and officers representing each sectoral organizational unit at the Transportation Ministry in crisis management. TKK is set up by the Minister based on a proposal from the Communication Working Unit (UKK), with the distribution of tasks and authority based on task and functions at the Transportation Ministry. The placement of personnel at TKK is based on the needs and competency needed by the ad hoc institution.

The post of TKK chief is stipulated as follows. If crisis communication is at national or international, cross sectoral and cross sub-sectoral levels, the chief of TKK is held by the Secretary General. The Inspector General is appointed to the post of TKK chief at the level of Inspectorate General. The Director General will be appointed TKK chief if there is crisis communication at the Directorate led by the Director General. The chief of board will be appointed TKK chief if there is crisis communication at the board concerned.

TKK comprises at least 3 (three) sections each of which is led by section coordinator, namely Media Monitoring and Analysis Section, Liaison Officer and Supporting Section and Media Relations Section.

Crisis Response Phase

After Ad Hoc TKK is set up, it later holds a coordination meeting with all TKK members. The administrative section soon prepares facilities for Crisis Center and is responsible for controlling the internal and external circulation of information. Internal circulation is distributing information to TKK and internal organizations at the Transportation Ministry. External circulation is holding communication with stakeholders related to disaster response, such as the National Commission for Transportation Safety, the National Search and Rescue Agency (Basarnas) and mass media.

Formulating "a holding statement" for public communication is an integral part of early activity after TKK is set up. The Media Monitoring and Analysis Section, along with the TKK chief formulate "key messages" and decide who will be a spokesperson to convey messages to the public. While formulating a holding statement, Mc Coombs (2007) recommends 10 crisis response strategies to improve or protect reputation. The strategies are divided into 4 different response strategy groups, namely denying, reducing, restoring and supporting (Coombs, 2007). The response strategies serve as a framework for formulating a holding statement.

It is not enough to conduct crisis response communication one time only. It depends on the time needed until the recovery or post-crisis phase. Thus, public communication in the form of press conference is held periodically during the crisis response period. Where a bomb attack on Marriot Hotel in 2003, a bomb attack on the Australian Embassy in 2004, and a deadly tsunami in Aceh in 2004 are concerned, the Indo Pacific, a communication consultant hired by the Indonesian government, held press conferences twice a day to convey latest developments (Dougall, et al, 2008). Thus, the Media Monitoring and Analysis Section monitors developing information related to disaster and sentiments circulating in mass media and online/social media. Disaster information is conveyed every 30 seconds to 1 minute in order to analyze crisis situation and make recommendations to the Communication Section to formulate crisis recovery messages (Roux, 2019).

\section{Post-Crisis and Reporting Phase}

Post-crisis phase is the phase of the end of crisis handling based on the declining or returningto-normal parameter of crisis. This means that the crisis status at the Transportation Ministry has been revoked based on several considerations decided by the TKK leadership, including the crisis which has passed the peak phase, the appointment of persons in charge of restoring affected human resources and identification of control plan and the declining frequency of reporting in mass media and online media.

In the post-crisis phase, the administrative section is responsible for job tasks, that is it coordinates with the communication section in terminating information services and informing external parties that the crisis has been over and TKK is no longer active. Likewise, the use of resources during the crisis handling is terminated and then a report is re made as a means of learning. When entering post-crisis communication, focus on crisis management has ended, however, crisis impact management continues. Post-crisis communication is mostly the expansion of crisis response communication plus learning from crisis. Lampel (2009) described learning as intentional and emerging process focusing on the event itself and the development of the organization's capacity outside crisis event (M Collins, 2016).

The whole process of crisis communication management in the handling of disaster starting from pre-crisis phase, crisis response phase to postcrisis phase can be seen from Figure 2. Going back to the previous issue, the Transportation Ministry 
as a bureaucratic organization finds it difficult to give rapid responses in the event of disaster that leads to a crisis.

Usually an organization which oversees many sub-sections which have the same scope of jobs is not always an homogeneous entity but can comprise sub-groups with different intentions, goals, agendas and priorities (Roshan et al., 2016). The condition is referred to as structural constraint due to the absence of common understanding in crisis communication management. The many pieces of evidence suggest that every organization has its own culture which in principle can influence the way how the organization reacts to internal crisis communication. The organizational culture formed at the Transportation Ministry portrays a bureaucratic organization with mechanistic model. This model explains a rigid organization, with stringent control, high level of hierarchy, clearly defined bureaucratic role and task, and centralized decision making. This condition leads to inability to develop creativity and innovation that may hinder faster performance (Hatch, M. J., \& Cunliffe, 2013).

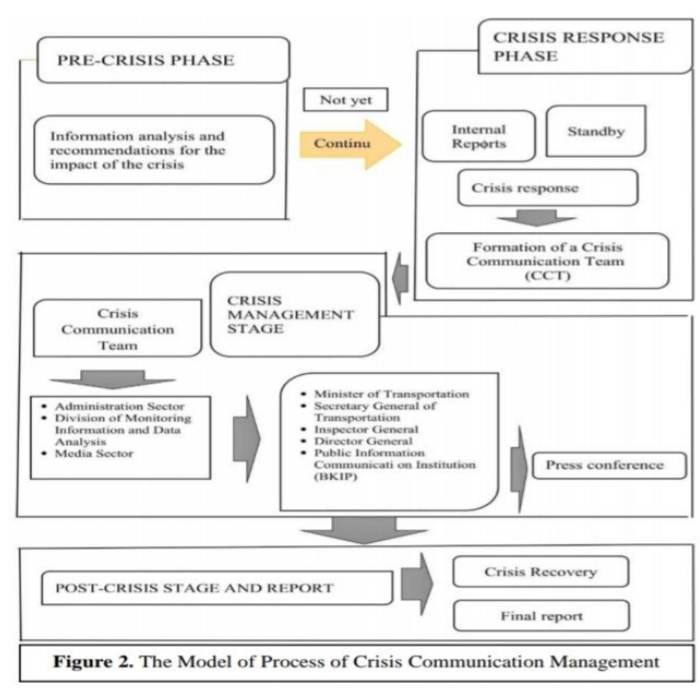

Figure 2. The Model of Process of Crisis Communication Management

The use of situational crisis communication theory framework in crisis communication management has practical significance to overcome structural constraints and build common understanding within the internal organization of the Transportation Ministry. The pre-crisis phase focusing on gathering information about crisis risks serves as interaction media for UKK of the Directorate General at the Transportation Ministry to identify potential crisis and later make a decision on how to manage the potential crisis. Interaction and communicative process are not found in vacuum but are influenced by the context of organization of which they are part (M Heide, 2015) Thus, in the pre-crisis phase, interaction and coordination among sections functions as a means to prepare a stage for the organization to prevent protracted crisis and serves as a shield for the organization to curtail various rumors or various forms of misinformation that may disrupt the credibility and reputation of the organization.

In this stage, crisis communication is concentrated on the placement ad reduction of risks. Prevention is the main priority for this anticipative model (Adkins, 2010). This model serves as an early detection effort in the pre-crisis phase to lay a basis for decision making and crisis prevention. Wan and Pfau (2004) recommended the use of pre-crisis messages to inject stakeholders about crisis (Matthew Collins et al., 2016).

In the crisis response phase, the formation of TKK offered a momentum to eliminate structural constraints and build common understanding about a disaster to conduct crisis communication management. This is because TKK personnel are the combination of officers from various subsectors within the internal organization of the Transportation Ministry. TKK serves as a means of cooperation and coordination to rescue the reputation and image of the organization. This is in line with the SCCT framework that stakeholders' reaction to crisis may have a behavior consequence on an organization and what is done and said by the organization during crisis may influence reputation. (van Rensburg, et al, 2017) .

The formation of TKK is also a form of improving the organization of the Transportation Ministry in disaster response. This, as explained by Heide and Simonsson, (2014), stresses that every crisis is unique. Thus, any organization must not pay too much attention to crisis management plan but must be able to make improvement. Regardless of the fact that improvement can turn flexible and 
accommodative, this does not mean that it is a random and spontaneous process but it is a process requiring experience, knowledge, flexibility and trust among members of the organization. (Mats Heide \& Simonsson, 2014)

SCCT theory directly gives guidance to the organization accustomed to hierarchic structure and centralized decision making. Crisis communication management with the model of pre-crisis, crisis response and post-crisis phases has made the organization more dynamic and responsive in disaster response. This is different from the theory of high-reliability organization (HRO) which works under model of uncertain crisis or in a state of emergency, (Agwu, et al, 2019). The HRO theory gives a framework to complex organization to work reliably in uncertain condition. This theory helps control and analyze routinity, policy procedure and strategy behind communication decision made in an unprecedented way. The framework of this theory has once been successful in handling crisis communication in times of Bali Bombs I and II (Dougall, et al, 2008))

\section{Conclusions}

This research finds the model of crisis communication management, starting from precrisis, crisis response to post-crisis phases. The model of pre-crisis phase gives a foundation to the Communication Working Unit at the Directorate General, the Inspectorate General and the Board along with BKIP to interact, communicate and coordinate in monitoring potential crisis. Such condition serves as media to overcome constraints in structurally hierarchic bureaucracy, and build common understanding about disaster response. The formation of Crisis Communication Team (TKK) has changed the organization from being under stringent hierarchic structure to being more dynamic and responsive in crisis response. The Crisis Communication Team worked until the crisis recovery or post-crisis phase and them made a report.

This research gives contributions to the Transportation Ministry in crisis communication management in order to be more dynamic and responsive in disaster response. This research also gives a recommendation and reference in formulating Standard Operating Procedure (SOP) which serves as rule mechanism in crisis communication management, starting from precrisis, crisis response to post-crisis phases. In addition, this research may provide guidance for government and non-government institutions in conducting crisis communication management.

Looking ahead, this research should focus on communication disparities between the
Transportation Ministry and external organizations related to the strategic partners of the Transportation Ministry, such as the National Commission for Transportation Safety (KNKT), the National Search and Rescue Agency (Basarnas) and other strategic partners in crisis communication management.

\section{Acknowledgements}

We are grateful to the Public Communication and Information Board (BKIP) at the Transportation Ministry for their trust in helping formulate crisis communication management at the Transportation Ministry.

\section{References}

Adamu, A. (2016). Antecedents of internal crisis communication and its consequences on employee performance. International Review of Management and Marketing, 6(7), 33-41.

Adkins, G. L. (2010). Organizational Networks in Disaster Response: An Examination of the US Government Network's Efforts in Hurricane Katrina. In Coombs and Holladay (Ed.), The Handbook of Crisis Communication (Fisrt, pp. 93-114). 2010 Blackwell Publishing Ltd. https://doi.org/10.1002/9781444314885.ch4

Agwu, A. E., Labib, A., \& Hadleigh-Dunn, S. (2019). Disaster prevention through a harmonized framework for high reliability organisations. Safety Science, 111, 298-312. https://doi.org/10.1016/j.ssci.2018.09.005

Al Shobaki, M. J., Abu Amuna, Y. M., \& Abu Naser, S. S. (2016). The impact of top management support for strategic planning on crisis management: Case study on UNRWA-Gaza Strip. International Journal of Academic Research and Development, 10(2), 20-25.

Andhika, L. R. (2018). Dari Struktur Birokrasi Tradsional Ke Model Adhocracy: Struktur Organisasi Inovatif. Publisia: Jurnal Ilmu Administrasi Publik, 3(1), 11-24.

Asteria, D. (2016). Optimalisasi Komunikasi Bencana di Media Massa sebagai Pendukung Manajemen Bencana. Jurnal Komunikasi Ikatan Sarjana Komunikasi Indonesia, 01(2), 1-11.

Brown, J. A., Buchholtz, A. K., \& Dunn, P. . (2016). Moral salience and the role of goodwill in firm-stakeholder trust repair. Business Ethics Quarterly, 26, 181-199.

Brown, N. A., \& Billings, A. C. (2013). Sports fans as crisis communicators on social media websites. Public Relations, 39(1), 74-81. 
Bundy, J., Pfarrer, M. D., Short, C. E., \& Coombs, W. T. (2017). Crises and Crisis Management: Integration, Interpretation, and Research Development, Journal of Management, 43(6).

Cardon, P. (2019). Leadership Communication on Internal Digital Platforms, Emotional Capital, and Corporate Performance: The Case for Leader-Centric Listening. International Journal of Business Communication. https://doi.org/10.1177/2329488419828808

Collins, M. (2016). Communication in a disaster the development of a crisis communication tool within the S-HELP project. Journal of Decision Systems, 25, 160-170. https://doi.org/10.1080/12460125.2016.118 7392

Collins, M., Neville, K., Hynes, W., Madden, M., Collins, M., Neville, K., Hynes, W., \& Madden, M. (2016). Communication in a disaster - the development of a crisis communication tool within the S-HELP project. 0125.

Coombs, T. Holladay, W. and S. J. (2010). The Handbook of Crisis Communication. In W. T. C. and S. J. Holladay (Ed.), Blackwell Publishing. John Wiley \& Sons Ltd,

Coombs, W. T. (2007). Protecting Organization Reputations During a Crisis: The Development and Application of Situational Crisis Communication Theory. Corporate Reputation Review, 10(3), 163-176.

Coombs, W. T. (2010a). Communication Key Definitions for Crisis. In W. and S. J. Coombs, T. Holladay (Ed.), The Handbook of Crisis Communication. Blackwell Publishing Ltd.

Coombs, W. T. (2010b). Parameters for Crisis Communication. In Combs and Haliday (Ed.), The Handbook of Crisis Communication. Blackwell Publishing Ltd.

Dominguez-Lopez, D. R.-T. and Y. (2017). Social Media in Crisis Communication: Germanwings Flight 4U9525 Diego. In F.C. Freire et al. (eds.) (Ed.), Media and metamedia management, Advances in Intelligent Systems and Computing 503, (pp. 243-249). Springer International Publishing Switzerland 2017. https://doi.org/10.1007/978-3-319-46068-0

Dougall, E. K., Horsley, J. S., \& McLisky, C. (2008). Disaster Communication: Lessons from Indonesia. International Journal of Strategic Communication, 2(2), 75-99. https://doi.org/10.1080/1553118080195818 8
Elliot, J. D. (2010). How do past crises affect publics' perceptions of current events? An experiment testing corporate reputation during an adverse event. The Handbook of Crisis Communication. John Wiley \& Sons.

Farida, A., \& Ganiem, L. M. (2017). Leader's Motivation Language - A Study on Internal Communication at National Library of Indonesia. Jurnal Komunikasi Ikatan Sarjana Komunikasi Indonesia, 2(1), 71-81. 10.25008/jkiski.v2i2.105

Frandsen, F., \& Johansen, W. (2018). Voices in Conflict? The Crisis Communication of Meta-Organizations. Management Communication Quarterly, 32(1), 90-120. https://doi.org/10.1177/0893318917705734

Hatch, M. J., \& Cunliffe, A. L. (2013). Organization Theory: Modern, Symbolic and Post Modern Perspective (3rd ed.). Oxford University Press New York.

Heide, M. (2015). Struggling with internal crisis communication: A balancing act between paradoxical tensions. Public Relations Inquiry, 4(2), 223-255.

Heide, Mats, \& Simonsson, C. (2014). Developing internal crisis communication: New roles and practices of communication professionals. Corporate Communications: An International Journal, 19(2), 128-146. https://doi.org/10.1108/CCIJ-09-2012-0063

Hong, L., Fu, C., Wu, J., \& Frias-Martinez, V. (2018). Information Needs and Communication Gaps between Citizens and Local Governments Online during Natural Disasters. Information Systems Frontiers, 20(5), 1027-1039. https://doi.org/10.1007/s10796-018-9832-0

Kádárová, J., Mihalčová, B., Kádár, G., \& Vida, M. (2015). Strategy Map for the Crisis Communication. Procedia Economics and Finance, 23(October 2014), 1119-1124. https://doi.org/10.1016/s22125671(15)00518-3

Peraturan Menteri Perhubungan Republik Indonesia Nomor PM 38 Tahun 2019, (2019).

Khosla, N. (2017). Communication Challenges and Strategies of U.S. Health Professionals Caring for Seriously Ill South Asian Patients and Their Families. Journal of Palliative Medicine, 20(6), 611-617.

Lestari, P., Astari, D. W., \& Asyrafi, A. L. (2019). Audit of Disaster Communication on TVOne Kabar Petang Program. Jurnal Komunikasi Ikatan Sarjana Komuniasi Indonesia, 4(2), 116-127. https://doi.org/10.25008/jkiski.v4i2.332 
Lestari, P., Prabowo, A., \& Wibawa, A. (2012). Manajemen Komunikasi Bencana Merapi 2010 pada saat Tanggap Darurat. Jurnal Ilmu Komunikasi, 10(2), 173-197.

Ly-Le, T.-M. (2018). Gaps in Perception on Social Media Use in Crisis Communication Between Vietnamese Organizations and Stakeholders. DeReMa (Development Research of Management): Jurnal Manajemen, 13(1), 11. https://doi.org/10.19166/derema.v13i1.768

Ma, L., \& Zhan, M. (Monica). (2016). Effects of attributed responsibility and response strategies on organizational reputation: A meta-analysis of situational crisis communication theory research. Journal of Public Relations Research, 28(2), 102-119. https://doi.org/10.1080/1062726X.2016.116 6367

Manoj, B. Y. B. S., \& Baker, A. H. (2007). Communication challenges in emergency response. Comunications of The ACM, 50(3), 51-53.

Mazzei, A. (2015). Internal crisis communication strategies to protect trust relationships: A study of Italian companies. International Journal of Business Communication, 52(3), 319-337. https://doi.org/10.1177/2329488414525447

Muslimin. (2018). Komisi V DPR Nilai Pemerintah Lamban Informasikan Jatuhnya Lion Air JT 610. Akurat.Co. https://akurat.co/id-368926read-komisi-v-dpr-nilai-pemerintahlamban-informasikan-jatuhnya-lion-air-jt610

Olaniran, B. A. \& D. E. W. (2008). Applying anticipatory and relational perspectives to the Nigerian delta region oil crisis. Public Relations Review, 34(1), 57-59.

Palttala, P., Boano, C., Lund, R., \& Vos, M. (2012). Communication Gaps in Disaster Management: Perceptions by Experts from Governmental and Organizations. Journal of Contingencies and Crisis Managemen, 20(1), 1-12.

Purworini, D. (2017). Crisis communication in an internal conflict: A social constructionist perspective, Pertanika Journal of Social Sciences and Humanities, Vol. 25, 1-10.

Ravazzani, S. (2016). Exploring internal crisis communication in multicultural environments: A study among Danish managers. Corporate Communications, 2l(1), 73-88. https://doi.org/10.1108/CCIJ02-2015-0011

Roshan, M., Warren, M., \& Carr, R. (2016).
Understanding the use of social media by organisations for crisis communication. Computers in Human Behavior, 63, 350361.

https://doi.org/10.1016/j.chb.2016.05.016

Roux, T. Le. (2019). Challenges in stakeholders self-organising to enhance disaster communication. Corporate Communications, 25(1), 128-142.

Sellnow, D. (2015). A Receiver-Based Approach to Effective Instructional Crisis Communication. Journal of Contingencies and Crisis Management, 23(3), 149-158. https://doi.org/10.1111/1468-5973.12066

Strandberg, J. M., \& Vigsø, O. (2016). Internal crisis communication: An employee perspective on narrative, culture, and sensemaking. Corporate Communications, 21(1), 89-102.

Ulmer, R. (2016). International Organizational Crisis Communication: A Simple Rules Approach to Managing Crisis Complexity. In The Handbook of International Crisis Communication Research (pp. 108-118). https://doi.org/10.1002/9781118516812.ch1 1

Van Rensburg, A., Conradie, D., \& Dondolo, H. (2017). the Use of the Situational Crisis Communication Theory To Study Crisis Response Strategies At a University of Technology. Communitas, 22(1), 62-74. https://doi.org/10.18820/24150525/comm.v 22.5

Wahyuni, H. I. (2019). Ecological Communication in Information Society: Reflections on Niklas Luhmann's Thought in Understanding Ecological and Disaster Issues in Indonesia. Jurnal Komunikasi Ikatan Sarjana Komunikasi Indonesia, 04(01), 9-17.

Wardyaningrum, D. (2016). Modal Sosial Inklusif Dalam Jaringan Komunikasi Bencana. Jurnal Aspikom, 3(1), 33-55.

Wowak, A. J., Mannor, M. J., \& Wowak, .D. (2015). Throwing caution to the wind: The effect of CEO stock option pay on the incidence of product safety problems. Strategic Management Journal, 36:, 10821092.

Zeng, J., Chan, C. H., \& Fu, K. W. (2017). How Social Media Construct "Truth" Around Crisis Events: Weibo's Rumor Management Strategies After the 2015 Tianjin Blasts. Policy and Internet, 9(3), 297-320. https://doi.org/10.1002/poi3.155 